\title{
Reactivity of silicate liming materials from Northern Europe assessed by Soil Incubation and two pH Stat methods
}

\author{
Karl-Jan Erstad \\ Consultative Agronomists, Lutelandet, N-6964 Korssund, Norway, \\ e-mail: karl-jan.erstad@raadgivande-agronomar.no
}

Nikolai Y. Konovalov

Regional Research Computer Centre, Lanskoe shosse 59-108, R-197343 St. Petersburg, Russia,

e-mail:nyk@comset.net

Jukka Putro

Rautaruukki Steel, Primary Products, PO Box 93, FIN-92101 Raahe, Finland, e-mail: jukka.putro@ rautaruukki.fi

Martin Rex

Versuchsanstalt Kamperhof, Mintarder Straße 264, D-45481 Mülheim an der Ruhr, Germany,

e-mail: rex@th-duenger.de

Elsa Luukkonen

Plant Production Inspection Centre, Agricultural Chemistry Department, PO Box 83, FIN-01301 Vantaa, Finland, e-mail: elsa.luukkonen@kttk.fi

Reactivity studies were carried out with a range of particle size fractions using one Norwegian ferro manganese slag, three Swedish and three Finnish blast furnace and converter slags. Their effect on soil $\mathrm{pH}$ was compared with a crystalline calcite. Besides establishing the slags' inherent liming ability, three methods were used in order to establish mathematical relationships for the conversion of data according to European standardisation. With the Soil Incubation method it was found that the converter slags and the amorphous blast furnace slags were slightly superior to the other slags in raising the soil $\mathrm{pH}$ of a silty loam, whereas in an acid peat the differences were quite small. Over a prolonged period the slags showed almost the same efficiency as the calcite. When comparing the same particle size fractions, in some cases the finer fraction of calcite gave a better result, whereas the slags were often superior in the coarse particle sizes. Using Sauerbeck/Rietz and the modified Finnish pH Stat methods the converter slags and the amorphous slags showed the highest neutralizing ability. The Finnish method performed a more gentle acid-lime reaction, and this time-consuming method correlated better with reaction in soil than the Sauerbeck/Rietz method. Conversion factors between data from the three methods were computed for all particle size fractions, and correlation equations for practical use established.

Key words: calcite, fineness, liming materials, reactivity, slags, soil 


\section{AGRICULTURAL AND FOOD SCIENCE IN FINLAND}

Erstad, K.-J. et al. Reactivity of silicate liming materials

\section{Introduction}

The production of hot metal and steel produces different types of slags (silicate materials). Hot metal production under reduced conditions results in a blast furnace slag with $30-40 \% \mathrm{SiO}_{2}$. The previous converter slag from the manufacture of pig iron was the famous Thomas slag, which contained about $4 \%$ P. The current slags in Northern Europe contain only one tenth of this. By air-cooling, a slag will be a homogenous crystalline product, and by water-cooling it will be amorphous and will consist of porous granules.

A range of experiments has been carried out to test the efficiency of slags as agricultural liming materials. The glassy ferro manganese slag from Øye Smelteverk was tested by Simán (1984) in two fractions, $0-0.1 \mathrm{~mm}$ and $0-3 \mathrm{~mm}$, and he found that the finer fractions had the greater liming effect, but were still inferior to chalk from Skåne. The Mg and in particular the Mn effects made it valuable as a special fertilizer, a fact that runs parallel to the recommendations for certain blast furnace slags made by Chichilo et al. (1954).

Other ferro slags with different features have been tested in Russia. Ogorodnikov and Novikov (1986) tested different liming materials in an acid derno-podzolic clay loam in the Ural region, adding lime to full hydrolytic soil acidity. Only a finely ground limestone raised the soil $\mathrm{pH}$ slightly more effectively than the applied ferro chromium slag. Sonina and Melnikova (1971) performed greenhouse experiments on an acid derno-podzolic loamy sand with $\mathrm{pH}_{\mathrm{KCl}} 4.2-4.4$, adding lime to full hydrolytic acidity. Without lime the $\mathrm{pH}$ dropped to $3.9-4.0$, but increased to 5.8, 4.9 and 5.9 when ferro chromium slag, blast furnace slag and ground limestone, respectively, were added.

In another liming experiment on a derno-podzolic soil using limestone, blast furnace slag and ferro alloy slag, Deryugin and Kultyshev (1973) found small differences. The ground limestone gave the best results for the yields of pea.
Blast furnace slag was better for winter rye and barley, and ferro alloy slag for potatoes. Myhr (1987, 1988) tested a 0-3 mm converter slag obtained from the Linz-Donavitz (LD) process at Norsk Jernverk AS. Due to its coarseness, its liming effect was inferior to finely ground limestone, but there were no differences in yield responses. On organic soils Myhr and Erstad (1996) found that the same slag was superior in maintaining $\mathrm{pH}$ in the long term, and $\mathrm{P}$, micronutrients and silica had an additional fertilizing effect. Penninck et al. (1986) proved that carbonate liming materials and finely ground LD slag from Belgium had an equal liming effect. Comparing the effect of different metallurgical slags Yagodin et al. (1994) observed that converter slag had a particularly stable effect on soil acidity even eight years after application. In the long term this was an even better effect than other slags and agricultural limes.

The particle size distribution of slags is the most important factor of their efficiency as liming materials. Jaakkola (1988) pointed out that air-cooled blast furnace slag required very fine grinding to achieve high $\mathrm{pH}$ levels in soil, whilst the water-cooled product was more effective. The ground converter slag was the most efficient in raising the soil pH. Avdonin (1976) considered that blast furnace slag was most effective if its particle size was less than $0.25-0.5 \mathrm{~mm}$. Kulakova et al. (1988) found that in the second year after application of converter slags, the highest increase in soil $\mathrm{pH}$ and base saturation, and simultaneous reduction in hydrolytic acidity, was obtained with a finely ground product. Particles coarser than $1.0 \mathrm{~mm}$ would only slightly influence yields during the first year after application, and dissolution of coarse particles above $2.5 \mathrm{~mm}$ would take many years (Dovgopol 1980). Russian technical specifications for the metallurgical slags used in agriculture require that the content of $\mathrm{CaCO}_{3}$ equiv. (equivalent) should be at least $80 \%$, maximum water content $2 \%, 100 \%$ of particles $\leq 2 \mathrm{~mm}, 90 \% \leq 0.5 \mathrm{~mm}$ and $70 \% \leq 0.25 \mathrm{~mm}$ (Avdonin 1976). In Finland (Statue Book of Finland 1994) the requirements for slags concern only NV (neutralizing value), 
Vol. 9 (2000): 333-348.

Table 1. Average concentrations of $\mathrm{Ca}$ and $\mathrm{Mg}$ and calculated $\mathrm{CaO}$ equivalents in the liming materials.

\begin{tabular}{llccc}
\hline Liming material & Abbreviation & $\mathrm{Ca}, \%$ & $\mathrm{Mg}, \%$ & $\begin{array}{c}\mathrm{CaO} \\
\text { equivalent } \\
\text { \%, calculated }\end{array}$ \\
\hline Breivik coarsely crystalline calcite & Breivik calcite & 39.4 & 0.2 & 55.1 \\
Ferro manganese slag, Øye Smelteverk, & Mn-Øye & 13.2 & 4.2 & 28.2 \\
M lime, blast furnace slag, SSAB Merox AB & M-Merox & 25.0 & 8.1 & 53.8 \\
K lime, blast furnace slag, SSAB Merox AB & K-Merox & 31.2 & 4.6 & 54.2 \\
Am-M lime, amorph. b.f. slag, SSAB Merox AB & am-M-Merox & 25.0 & 8.1 & 53.8 \\
BF slag, blast furnace slag, Rautaruukki OY & BF-Rauta & 26.6 & 7.0 & 53.4 \\
BOF slag, converter slag, Rautaruukki OY & BOF-Rauta & 36.6 & 1.0 & 53.6 \\
Mg-BOF slag, 50/50 BF/BOF, Rautaruukki OY & Mg-BOF-Rauta & 32.9 & 2.5 & 52.2 \\
\hline
\end{tabular}

and the minimum levels are $30 \% \mathrm{Ca}$ for converter slags and $25 \% \mathrm{Ca}$ for blast furnace slags. The previous Norwegian standard 2885 (Norges Standardiseringsforbund 1987) required only that slags should contain at least $30 \% \mathrm{CaO}$ equivalent. Moreover, Dovgopol (1980) compared the effects of slag with the usual liming materials. He mentions the additional benefits of the multilateral effects of slags due to their additional acid soluble content of phosphorus, sulphur, micro- and macronutrients and other silica elements. Volk et al. (1952), Vetter (1974), Rex and Munk (1989) pointed out that crop response to slags is not predictable from soil reactions alone, but could also be related to the silica effect. Carter et al. (1951) found that a US agricultural grade air-cooled blast furnace slag containing boron was a highly valuable fertilizer on boron deficient loamy soils.

The purpose of the present experiment was to determine the liming efficiency of particle size fractions of different slags in order to classify them in the forthcoming European standards. In addition, conversion factors between different analytical methods are needed for reference in the production of standards and the subsequent advisory work. This study augments the work by comparing the results obtained from two quick laboratory methods. These results are compared with a soil incubation method. The soil incubation method is designed to show the actual liming effect in the soil. A preliminary report related to short term effects of the slags in this research work has been published (Erstad et al. 1994).

\section{Material and methods}

\section{Material}

The silicate liming products chosen for the experiments were the most relevant silicate products (slags) from the participating companies Øye Smelteverk, Tinfos Jernverk AS (Kvinesdal, Norway), SSAB Merox AB (Oxelösund, Sweden) and Rautaruukki OY (Raahe, Finland). Breivik (Norway) coarsely crystalline calcite was included as a reference. This product is well known from several other reactivity tests. Table 1 shows the average values of $\mathrm{Ca}$ and $\mathrm{Mg}$ content in these liming materials, determined according to prEN 13475 (2000) and EN 12947 (2000) respectively, and calculated figures of $\%$ $\mathrm{CaO}$ equiv. $=[\% \mathrm{CaO}]+[\% \mathrm{MgO} \times 1.4]$, a term which is very close to NV (neutralizing value) according to prEN 12945 (2000). There were very small differences in chemical composition between fractions of each material. The converter slags had a higher content of reactive calcium oxide and some magnesium oxide compared with the blast furnace slags. The ferro manganese slag from Øye Smelteverk contained only half the level of $\mathrm{CaO}$ equivalent compared to the others, 
Erstad, K.-J. et al. Reactivity of silicate liming materials

Table 2. Chemical analyses of the mineral soil from Askvoll, Norway, and the Norwegian natural peat, used in the soil incubation experiment.

\begin{tabular}{|c|c|c|c|c|c|c|c|c|c|}
\hline \multirow[t]{2}{*}{ Soil } & \multirow{2}{*}{$\begin{array}{c}\text { Soil } \\
\text { density, } \\
\mathrm{kg} \mathrm{dm}^{-3}\end{array}$} & \multirow{2}{*}{$\begin{array}{c}\text { Organic } \\
\text { matter, } \\
\%\end{array}$} & \multirow[t]{2}{*}{$\mathrm{pH}$} & \multicolumn{5}{|c|}{ Exchangeable cations } & \multirow{2}{*}{$\begin{array}{c}\text { Base } \\
\text { saturation, } \\
\%\end{array}$} \\
\hline & & & & $\mathrm{Ca}^{2+}$ & $\mathrm{Mg}^{2+}$ & $\begin{array}{c}\mathrm{K}^{+} \\
\mathrm{cmol}(+\end{array}$ & $\mathrm{g}^{-1} \mathrm{Na}^{+}$ & $\mathrm{H}_{3} \mathrm{O}^{+}$ & \\
\hline Mineral soil & 0.91 & 10.7 & 5.1 & 1.26 & 0.54 & 0.19 & 0.19 & 20.0 & 9.8 \\
\hline Natural peat & 0.04 & 95.9 & 4.2 & 3.67 & 3.41 & 0.13 & 1.20 & 171.0 & 4.7 \\
\hline
\end{tabular}

and it was comparatively high in manganese $(15.9 \% \mathrm{Mn})$.

The soils used for the soil incubation experiments, represent the two main groups in Northern Europe: Loamy soils, described in the reactivity method (Norges Standardiseringsforbund 1987), and ombrogenous peats. The silty loam soil (Hodgson 1974) was brought from Strømmen in Askvoll, Sunnfjord in Norway, and consisted of $11.3 \%$ sand, $73.2 \%$ silt and $15.5 \%$ clay. The peaty soil was a purchased natural product (Hydro Huminal), and was chosen to investigate the particular effects of acid organic matter on lime dissolution. The soil chemical analyses are given in Table 2.

The soil density values were obtained by following the procedure described by Bondorff (1950). Loss on ignition was measured at $823 \mathrm{~K}$ for $12 \mathrm{~h}$, and the organic matter calculated by subtracting the hygroscopic water held in the clay minerals of the soil and obtained from standard tables of correction, referenced by Scheffer and Schachtschabel (1979). pH( $\left.\mathrm{H}_{2} \mathrm{O}\right)$ was measured in distilled water using a soil to water ratio of 1:2.5 v/v. Exchangeable $\mathrm{H}, \mathrm{Ca}, \mathrm{Mg}, \mathrm{K}$ and $\mathrm{Na}$ were extracted using the $\mathrm{NH}_{4} \mathrm{OAc}$ method $\mathrm{pH}$ 7.00, as described by Thomas (1982). The acidity was determined by back titration to $\mathrm{pH} 7.00$, and $\mathrm{Ca}, \mathrm{Mg}, \mathrm{K}$ and $\mathrm{Na}$ by atomic absorption spectrometry. Base saturation was determined by calculation.

\section{Laboratory methods}

Terminology of reaction of liming materials

Reactivity is the rate of reaction of a liming ma- terial with acid (soil or solution) under specified conditions (prEN 12944-3 2000).

Neutralising value is the ability of a liming material to neutralise soil or solution acidity, measured in accordance with prEN 12945 (2000). It is a number, which represents the amount in kilograms of calcium oxide $(\mathrm{CaO})$ which has the same neutralising effect as $100 \mathrm{~kg}$ of the product under consideration (prEN 129443 2000).

The Effectiveness of a liming material is its ability to dissolve in soil or solution, measured relatively to its neutralising value, given at a fixed time of reaction.

The Efficiency of a liming material is its effectiveness over a period of time.

Effectiveness and efficiency data are generally given for each particle size fraction of the liming material being evaluated.

The Effective neutralising value (ENV) of a liming material is equal to its neutralising value multiplied with its effectiveness in soil at fixed times, normally 1 and 5 years.

\section{The Soil Incubation method}

The Soil Incubation method is a laboratory procedure intended to demonstrate the reactivity of liming materials under agricultural conditions (Erstad 1992). Because the experiment was conducted in the laboratory at constant $293 \mathrm{~K}$, the rate was faster than in the field. Seasonal climatic variations are eliminated. The liming materials were sieved and the following 11 fractions were isolated: $<0.063,0.063-0.2,0.2-0.4$, $0.4-0.6,0.6-0.8,0.8-1.0,1.0-1.4,1.4-1.6,1.6-$ $2.0,2.0-3.15$ and $3.15-5.0 \mathrm{~mm}$. These separate fractions were used in this study. Increments 
Vol. 9 (2000): 333-348.

were thoroughly mixed into the soil at two levels, corresponding to 3000 and $6000 \mathrm{~kg} \mathrm{CaO}$ equiv. ha-1 in a $20 \mathrm{~cm}$ plough layer. Each limed treatment had two replicates, and each zero treatment had four replicates.

One litre of normally compacted dried soil and the liming materials to be tested were mixed and water was added to a $70 \%$ water holding capacity for mineral soils, and $60 \%$ for organic soils. The incubation was performed on a barren soil. The pots were covered with a parafilm during the incubation period of 130 weeks. It was removed 5-7 days before each sampling. Samples were taken at 1, 3, 6, 12, 24, 52, 78, 104 and 130 weeks after liming.

On each sampling date, $10 \mathrm{~cm}^{3}$ of soil was collected from each pot separately with a miniauger, then mixed and stirred with distilled water at a soil:water ratio of 1:2.5 v/v for $5 \mathrm{~min}-$ utes and the $\mathrm{pH}$ measured after one night. The equipment used for $\mathrm{pH}$ measurements was a METROHM 654 digital $\mathrm{pH}$ meter with separate electrodes.

The $\mathrm{pH}$ effects on each soil were calculated by subtracting the average $\mathrm{pH}$ value of the zero treatment from those of the limed treatments.

Because there is linearity between liming and $\mathrm{pH}$ in the range 4.5-6.5(7.0), the conversion of the $\mathrm{pH}$ increase to the effectiveness of liming materials could be established. The finest fractions of calcite $(<0.063 \mathrm{~mm})$ are known to dissolve immediately, and as $\mathrm{pH}$ dropped for this material due to acidifying reactions in soil, the peaks of slightly coarser calcite fractions reached their maximum, and this maximum was set to $100 \%$ dissolution, as $\mathrm{pH}$ development was closely studied. This implied that the finer fractions of calcite were set to $100 \%$ dissolution, too, because these were known to have had their effect already. Correspondingly the finer fractions of silicates were set equal to the peak dissolution value within each liming material. The reactivity of a fraction was calculated as the effectiveness of the fraction compared to the completely dissolved fractions of the given slag type.

The data for 24 and 130 weeks were equivalent to the ENV (effective neutralising value =
NV x reactivity in soil) over the course of 1 year and 5 years, respectively, according to Erstad (1992). By multiplying the given data of effectiveness with results from analyses of $\mathrm{CaO}$ equivalent and by performing the experiment by particle size fraction, the reactivity of any liming material can be calculated by multiplying the reactivity fractionwise with its particle size distribution, and subsequently summarised.

\section{The Sauerbeck/Rietz, method}

The currently adopted German method was a potentiometric titration of aqueous carbonate suspensions with $\mathrm{HCl}$ at $\mathrm{pH} 2.0$ according to Sauerbeck and Rietz (1985). The $\mathrm{pH}$ stat titration period was $10 \mathrm{~min}$. Results were given as per cent dissolution of $\mathrm{CaCO}_{3}$ equiv. for each particle size fraction. These $\mathrm{CaCO}_{3}$ equiv. values were calculated from analyses of $\mathrm{Ca}$ and $\mathrm{Mg}$, and were a little higher than neutralising values determined by titration according to prEN 12945 (2000).

\section{The modified Finnish pH Stat method}

The unpublished Finnish method was described by the Plant Production Inspection Centre as a 'Fast acting neutralising capability of liming materials with the pH Stat method.' The method was an automatic potentiometric titration, where each sample of liming material was leached for 24 hours in a water suspension, while $\mathrm{pH}$ was constantly kept at 5.0 by adding $0.4 \mathrm{M}$ nitric acid $\left(\mathrm{HNO}_{3}\right)$ into the titration vessel, as soon as the $\mathrm{pH}$ of the solution tended to rise. The titration solution was stirred with a magnetic blender to prevent the finest particles settling out on the bottom of the beaker. The sample of liming material was put into a net basket cylinder made of an acid proof steel net (openings $0.15 \mathrm{~mm}$ ). This cylinder was attached to a lateral stalk, and moved up and down in the solution at 30 strokes/ min (length of stroke $50 \mathrm{~mm}$ ).

The effectiveness was assessed by measuring the consumption of $\mathrm{HNO}_{3}$ during the analysis. The result was given as $\%$ dissolved $\mathrm{Ca}$ (pHstatFIN), and it did not take impurities into account. To establish a correlation with the re- 
Erstad, K.-J. et al. Reactivity of silicate liming materials

sults of the two other methods, the chemical purity of the liming materials was taken into account by applying the following correction factors:

pHcorrectedFIN $=\frac{\text { HHstatFIN } \times 40.08}{\% \text { Ca equiv. }}$

where $40.08=\frac{100 \times \mathrm{Ca}}{\mathrm{CaCO}_{3}}$

$\% \mathrm{Ca}$ equiv. $=[\% \mathrm{Ca}]+[\% \mathrm{Mg} \times 1.65]$

\section{Statistical methods}

All analyses of variance were made using the Statistical Analysis System (SAS), Release 6.03 (SAS Institute 1985, 1987, 1988). To test the differences of $\mathrm{pH}$ increases after 24 and 130 weeks of incubation, comparisons were performed by means of the Ryan-Einot-GabrielWelsch Multiple Q Test (REGWQ) at the 5\% level (type I experimentwise error rate). The procedure SUMMARY was used to calculate the conversion factors $\left(\operatorname{convf}_{\mathrm{n}}\right.$ ) fraction by fraction applying different methods to determine the reactivity of liming materials. Linear correlation equations were established as follows:

Reactivity $($ method 2$)=\left(\operatorname{convf}_{1} \times \mathrm{f}_{1}+\operatorname{convf}_{2}\right.$ $\left.\mathrm{x}_{2} \ldots . .+\operatorname{convf}_{11} \mathrm{xf}_{11}\right) *$ Reactivity(method 1 )

where $f_{1}-f_{11}=$ relative mass of each particle size group, from the finest to the coarsest.

\section{Results and discussion}

\section{The Soil Incubation method}

\section{Tests with the silty loam}

The effects on soil $\mathrm{pH}$ of the highest level of liming (6000 kg CaO equiv. ha-1) are given in Figs. 1-3 for three representative types of liming materials, the Breivik calcite, the BF-Rauta and the BOF-Rauta. The finest particle size fractions reacted immediately with the soil colloids and increased the $\mathrm{pH}$ levels. The intermediate fractions, e.g. $0.8-1.0 \mathrm{~mm}$, raised the soil $\mathrm{pH}$

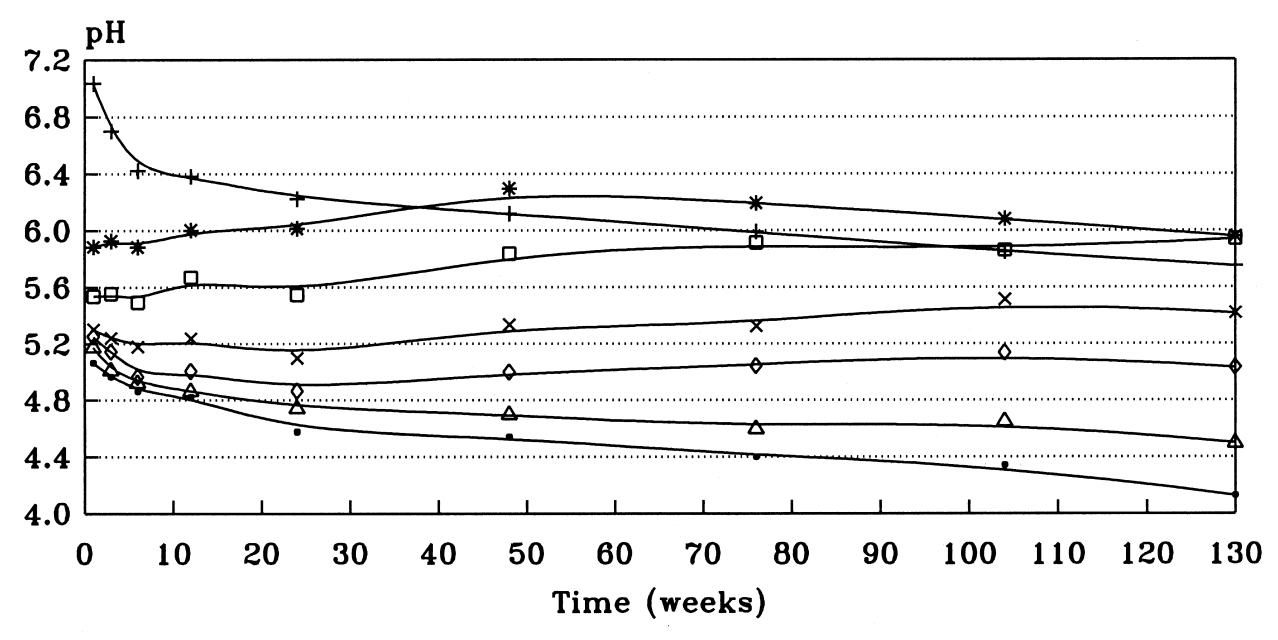

Part. size fraction

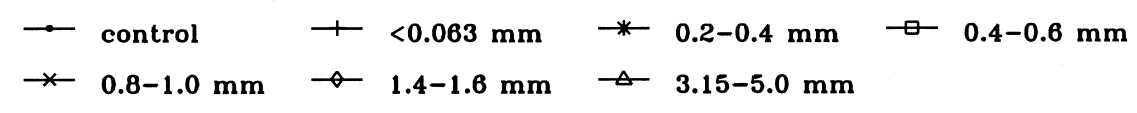

Fig. 1. $\mathrm{pH}$ effects for particle size fractions $(\mathrm{mm})$ of Breivik calcite at highest level (6000 $\mathrm{kg} \mathrm{CaO}$ equivalents per ha) in a silty loam from Askvoll, Norway, during 2.5 years (130 weeks) of incubation. 


\section{AGRICULTURAL AND FOOD SCIENCE IN FINLAND}

Vol. 9 (2000): 333-348.

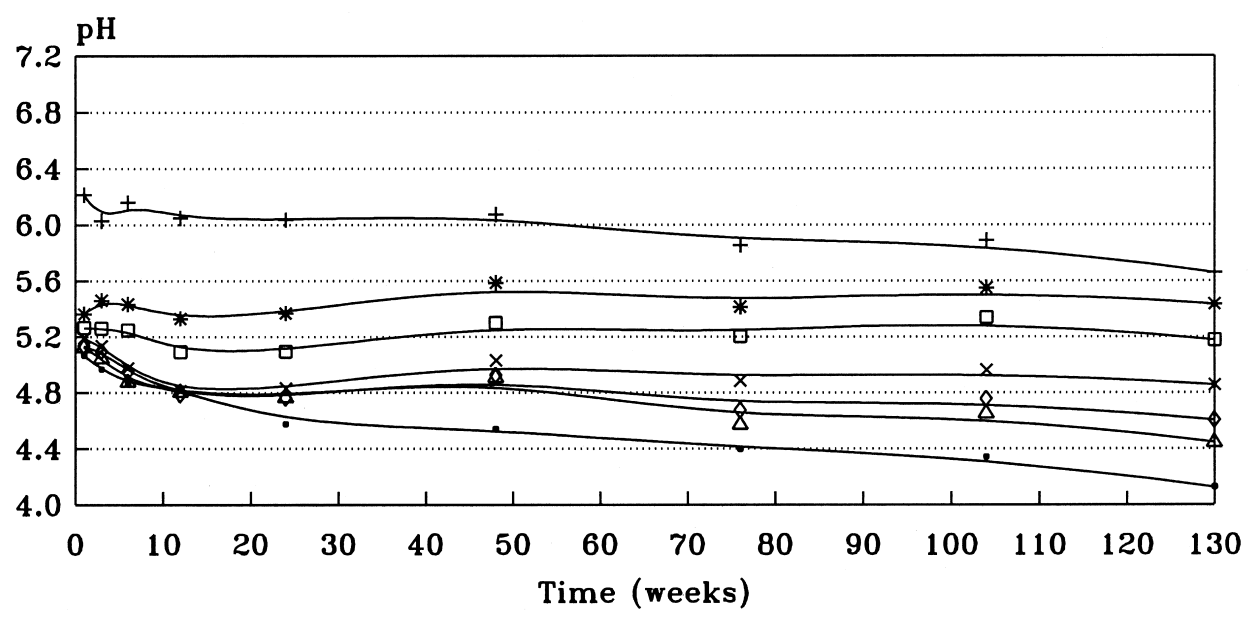

Part. size fraction

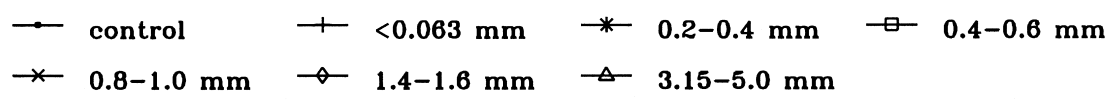

Fig. 2. pH effects for particle size fractions (mm) of BF-Rauta (blast furnace slag) at highest level $(6000 \mathrm{~kg}$ $\mathrm{CaO}$ equivalents per ha) in a silty loam from Askvoll, Norway, during 2.5 years (130 weeks) of incubation.

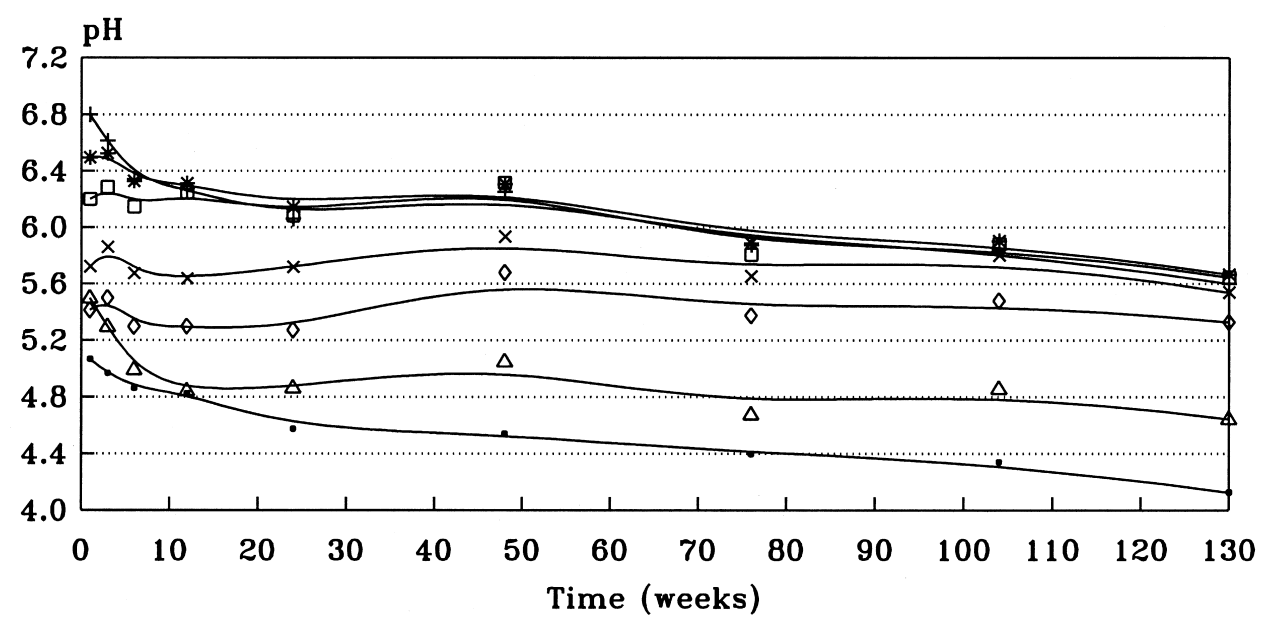

Part. size fraction

$$
\begin{aligned}
& \rightarrow \text { control } \rightarrow<0.063 \mathrm{~mm} \rightarrow 0.2-0.4 \mathrm{~mm} \rightarrow 0.4-0.6 \mathrm{~mm}
\end{aligned}
$$

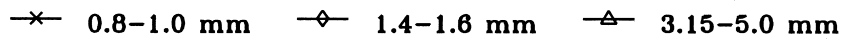

Fig. 3. pH effects for particle size fractions (mm) of BOF-Rauta (converter slag) at highest level (6000 kg $\mathrm{CaO}$ equivalents per ha) in a silty loam from Askvoll, Norway, during 2.5 years (130 weeks) of incubation. 


\section{AGRICULTURAL AND FOOD SCIENCE IN FINLAND}

\section{Erstad, K.-J. et al. Reactivity of silicate liming materials}

quite slowly during the first weeks, especially in the case of the BF-Rauta slag, but the effectiveness increased during 130 weeks. The coarsest particle size fractions, in particular 3.15-5.0 $\mathrm{mm}$, demonstrated a very low effectiveness, and with exception of the BOF-Rauta slag, this was the case for the entire incubation period.

In general the highest $\mathrm{pH}$ values were obtained with Breivik calcite, at least in the short term, and the lowest $\mathrm{pH}$ values with the Mn-Øye slag. The converter slags (K-Merox and BOFRauta) were superior to the blast furnace slags (M-Merox and BF-Rauta) in their ability to raise soil $\mathrm{pH}$ during the first weeks, but the differences were gradually reduced. The am-M-Merox appeared to be slightly more effective than the ordinary M-Merox, and this was particularly true for the finest particle size fractions.

Table 3 shows the mean effects for both liming levels, and the REGWQ Test results for the silicate liming materials, tested by selected fractions and measured relative to Breivik calcite $<0.063 \mathrm{~mm}$. A combination of the two liming levels proved to be reasonable, because the low level overestimated the effects of coarse particles in an acid soil, whilst the high level was an over-liming which underestimated the liming effect of the same coarse fractions. The chosen times of measurements, at 24 and 130 weeks of incubation, correspond to ENV values at 1 and 5 years. It was apparent that the converter slags in general were superior, especially their coarser fractions in the last period. For the finer fractions no significant differences could be found between blast furnace and converter slags after 130 weeks. Am-M-Merox achieved its peak effectiveness in the fraction below $0.2 \mathrm{~mm}$. The $\mathrm{Mn}-\varnothing$ ye was generally inferior to the other slags. In the long term the most effective slags did not differ from the Breivik calcite.

In the Soil Incubation experiment the reactivities of the finer fractions $(<0.6 \mathrm{~mm})$ of the blast furnace and converter slags were slightly lower than those of the calcite (Table 4$)$. The coarser fractions $(>0.8 \mathrm{~mm})$ of the converter slags were superior to the other slags of similar particle size in increasing $\mathrm{pH}$ levels. This was even the case for the blast furnace slag M-Merox for the first period. The Mg-BOF-Rauta was a mixture of BF-Rauta and BOF-Rauta, and its reactivity was intermediate between its parent materials. The reactivity of Mn-Øye was very low, even lower than that reported for an unground 'quenched' slag (glassy calcium silicate) by MacIntire et al. (1946), and this is probably related to its extremely low porosity and dense surfaces.

\section{Tests with the peaty soil}

In the Soil Incubation experiment with peat (Table 5) there were fewer statistically significant differences between the liming materials when compared with the incubation in the silty loam. Larger variations could be traced back to spot effects around the liming material particles in the aggressive peat. There were scarcely any differences between the blast furnace and converter slags in this acid peat. The higher content of reactive oxides in the converter slags gave them no clear advantage. The coarser particles of Breivik calcite seemed to be more effective in the long term, and it was evident that its coarse crystallinity did not hamper its dissolution in this acid peaty soil. Even the Mn-Øye slag increased soil pH quite effectively in this experiment, although it was clearly inferior to the other slags.

Based on the Soil Incubation reactivity data in the peat (Table 6), the amorphous M-Merox exhibited almost the same dissolution as the Breivik calcite, followed by the ordinary blast furnace slags. The converter slags were somewhat lower in reactivity, and the Mn- $\varnothing$ ye was the least reactive. The finer particles $(<1.0 \mathrm{~mm})$ of the mixed $\mathrm{Mg}$-BOF slag gave results which are difficult to explain. It was expected that they would be an average of the BF and BOF slag parent materials. For coarser materials the data were as expected.

Previous investigations were mainly performed on mineral soils, with exception of parts of the experiments of Jaakkola (1988), which, identically with these results, showed that coarser particles of all liming materials tested were more efficient in the peat compared with the 
Vol. 9 (2000): 333-348.

Table 3. Mean effect values (\%) and REGWQ tests for silicate liming materials, tested by fractions and measured relatively to Breivik calcite $<0.063 \mathrm{~mm}, 24$ and 130 weeks after start of incubation in a silty loam from Askvoll, Norway. The results of all the particle size fractions and the two reaction times were tested separately.

\begin{tabular}{|c|c|c|c|c|c|c|}
\hline $\begin{array}{l}\text { REGWQ } \\
\text { Grouping }\end{array}$ & $\begin{array}{c}\text { Mean } \\
24 \text { weeks }\end{array}$ & Ranking 24 weeks & Liming material & Ranking 130 weeks & $\begin{array}{l}\text { REGWQ } \\
\text { Grouping }\end{array}$ & $\begin{array}{c}\text { Mean } \\
130 \text { week }\end{array}$ \\
\hline & & & Fraction $<0.063 \mathrm{~mm}$ & & & \\
\hline A & 100.4 & BOF-Rauta & & am-M-Merox & A & 103.3 \\
\hline A & 100.0 & Breivik calcite & & Breivik calcite & A & 100.0 \\
\hline A & 92.2 & am-M-Merox & & BOF-Rauta & A & 96.0 \\
\hline A & 92.1 & Mg-BOF-Rauta & & BF-Rauta & A & 95.3 \\
\hline A & 90.4 & BF-Rauta & & Mg-BOF-Rauta & $\mathrm{AB}$ & 90.5 \\
\hline A & 86.3 & K-Merox & & M-Merox & A B & 90.1 \\
\hline A & 84.3 & M-Merox & & K-Merox & B & 79.5 \\
\hline B & 15.4 & Mn-Øye & & Mn-Øye & $\mathrm{C}$ & 22.6 \\
\hline
\end{tabular}

$\begin{array}{rrl}\text { A } & 108.0 & \text { Breivik calcite } \\ \text { A B } & 100.0 & \text { BOF-Rauta } \\ \text { B C } & 85.2 & \text { Mg-BOF-Rauta } \\ \text { B C } & 85.1 & \text { K-Merox } \\ \text { C } & 80.9 & \text { BF-Rauta } \\ \text { C } & 76.8 & \text { M-Merox } \\ \text { C } & 74.3 & \text { am-M-Merox } \\ \text { D } & 18.1 & \text { Mn-Øye }\end{array}$

Fraction $0.063-0.2 \mathrm{~mm}$

$\begin{array}{lrr}\text { BF-Rauta } & \text { A } & 104.5 \\ \text { Breivik calcite } & \text { A } & 102.2 \\ \text { BOF-Rauta } & \text { A B } & 96.7 \\ \text { am-M-Merox } & \text { A B } & 92.7 \\ \text { Mg-BOF-Rauta } & \text { A B } & 88.5 \\ \text { M-Merox } & \text { B } & 84.0 \\ \text { K-Merox } & \text { B } & 82.1 \\ \text { Mn-Øye } & \text { C } & 22.2\end{array}$

$\begin{array}{lll}\text { A } & 79.2 & \text { BOF-Rauta } \\ \text { B } & 62.7 & \text { K-Merox } \\ \text { B } & 55.5 & \text { Mg-BOF-Rauta } \\ \text { B C } & 49.6 & \text { Breivik calcite } \\ \text { C D } & 34.1 & \text { M-Merox } \\ \text { D E } & 29.0 & \text { BF-Rauta } \\ \text { D E } & 21.5 & \text { am-M-Merox } \\ \text { E } & 12.0 & \text { Mn-Øye }\end{array}$

Fraction $0.6-0.8 \mathrm{~mm}$

Breivik calcite
BOF-Rauta
K-Merox
Mg-BOF-Rauta
BF-Rauta
M-Merox
am-M-Merox
Mn-Øye

$\begin{array}{rrr}\text { A } & & 107.7 \\ \text { A B } & & 92.0 \\ \text { B } & 85.2 \\ \text { B } & 81.0 \\ \text { C } & 60.0 \\ \text { C } & 58.2 \\ \text { C D } & 46.9 \\ & \text { D } & 28.4\end{array}$

$\begin{array}{rrl}\text { A } & 47.3 & \text { BOF-Rauta } \\ \text { B } & 38.4 & \text { Mg-BOF-Rauta } \\ \text { B C } & 28.7 & \text { K-Merox } \\ \text { C D } & 25.2 & \text { M-Merox } \\ \text { C D E } & 18.8 & \text { am-M-Merox } \\ \text { C D E } & 18.7 & \text { Breivik calcite } \\ \text { D E } & 16.3 & \text { BF-Rauta } \\ \text { E } & 9.6 & \text { Mn-Øye }\end{array}$

Fraction 1.0-1.4 mm

BOF-Rauta
Breivik calcite
Mg-BOF-Rauta
K-Merox
M-Merox
BF-Rauta
am-M-Merox
Mn-Øye

\begin{tabular}{rrr} 
A & & 75.5 \\
A B & & 70.4 \\
B & & 64.0 \\
B & 59.5 \\
C & 44.8 \\
C & 37.5 \\
C & 36.4 \\
\multicolumn{2}{r|}{ D } & 20.2
\end{tabular}

\begin{tabular}{rrl} 
A & 26.0 & BOF-Rauta \\
A B & 19.4 & K-Merox \\
A B C & 16.1 & M-Merox \\
B C & 14.2 & Mg-BOF-Rauta \\
B C & 12.1 & BF-Rauta \\
C & 8.6 & Breivik calcite \\
C & 6.1 & Mn-Øye \\
\hline
\end{tabular}

Fraction $2.0-3.15 \mathrm{~mm}$

BOF-Rauta
K-Merox
M-Merox
Mg-BOF-Rauta
Breivik calcite
BF-Rauta
Mn-Øye

$\begin{array}{lll}\text { A } & 42.9 \\ \text { B } & 33.5 \\ \text { B } & 32.1 \\ \text { B } & 31.5 \\ \text { B } & 31.1 \\ \text { B } & 27.4 \\ \text { C } & 14.7\end{array}$


Erstad, K.-J. et al. Reactivity of silicate liming materials

Table 4. Reactivity in the course of 1 year and 5 years according to the Soil Incubation method for particle size groups (mm) of the Breivik reference calcite and the silicate liming materials in a silty loam from Askvoll, Norway. Average values for liming levels 1 and 2 .

\begin{tabular}{|c|c|c|c|c|c|c|c|c|}
\hline \multirow{2}{*}{$\begin{array}{l}\text { Fraction } \\
\mathrm{mm}\end{array}$} & \multicolumn{8}{|c|}{ Liming material } \\
\hline & $\begin{array}{c}\text { Breivik } \\
\text { calcite }\end{array}$ & Mn-Øye & $\begin{array}{c}\text { M- } \\
\text { Merox }\end{array}$ & $\begin{array}{c}\text { K- } \\
\text { Merox }\end{array}$ & $\begin{array}{l}\text { am-M- } \\
\text { Merox }\end{array}$ & $\begin{array}{c}\text { BF- } \\
\text { Rauta }\end{array}$ & $\begin{array}{l}\text { BOF- } \\
\text { Rauta }\end{array}$ & $\begin{array}{c}\text { Mg-BOF- } \\
\text { Rauta } \\
\end{array}$ \\
\hline & \multicolumn{8}{|c|}{ Reactivity in 1 year } \\
\hline$<0.063$ & 100.0 & 17.7 & 77.9 & 81.9 & 84.8 & 83.8 & 94.3 & 84.9 \\
\hline $0.063-0.2$ & 100.0 & 17.7 & 70.9 & 81.9 & 68.5 & 74.8 & 94.3 & 78.9 \\
\hline $0.2-0.4$ & 82.6 & 17.7 & 53.8 & 81.9 & 40.4 & 50.7 & 94.3 & 71.0 \\
\hline $0.4-0.6$ & 63.9 & 13.3 & 40.4 & 73.2 & 25.8 & 35.5 & 88.9 & 66.2 \\
\hline $0.6-0.8$ & 45.6 & 11.1 & 31.7 & 58.2 & 20.0 & 26.7 & 73.6 & 51.6 \\
\hline $0.8-1.0$ & 27.7 & 11.3 & 28.4 & 44.2 & 20.6 & 21.5 & 64.6 & 43.8 \\
\hline $1.0-1.4$ & 17.5 & 8.8 & 23.4 & 26.8 & 17.4 & 15.2 & 44.3 & 35.6 \\
\hline $1.4-1.6$ & 14.2 & 8.0 & 21.8 & 29.1 & 17.3 & 13.6 & 36.7 & 27.5 \\
\hline $1.6-2.0$ & 11.3 & 7.2 & 17.9 & 23.8 & 8.6 & 10.9 & 39.0 & 26.5 \\
\hline $2.0-3.15$ & 7.8 & 5.6 & 14.9 & 18.1 & - & 11.4 & 24.4 & 13.3 \\
\hline \multirow[t]{2}{*}{$3.15-5.0$} & 9.7 & - & 10.1 & 10.5 & - & 10.6 & 11.3 & 10.9 \\
\hline & \multicolumn{8}{|c|}{ Reactivity in 5 years } \\
\hline$<0.063$ & 100.0 & 24.2 & 77.9 & 81.9 & 88.4 & 89.5 & 94.3 & 90.0 \\
\hline $0.063-0.2$ & 100.0 & 24.2 & 71.9 & 81.9 & 79.3 & 89.5 & 94.3 & 90.0 \\
\hline $0.2-0.4$ & 100.0 & 24.2 & 68.7 & 81.9 & 61.1 & 73.9 & 94.3 & 83.5 \\
\hline $0.4-0.6$ & 100.0 & 24.2 & 57.9 & 74.6 & 47.2 & 60.2 & 88.9 & 69.8 \\
\hline $0.6-0.8$ & 92.0 & 24.2 & 49.9 & 73.2 & 40.1 & 51.4 & 78.8 & 69.4 \\
\hline $0.8-1.0$ & 68.8 & 22.9 & 48.2 & 69.7 & 34.8 & 43.0 & 74.9 & 63.8 \\
\hline $1.0-1.4$ & 60.4 & 17.3 & 38.4 & 51.0 & 31.1 & 32.1 & 65.0 & 55.0 \\
\hline $1.4-1.6$ & 50.5 & 17.6 & 37.6 & 46.4 & 28.7 & 25.6 & 60.4 & 48.1 \\
\hline $1.6-2.0$ & 35.8 & 14.4 & 29.8 & 37.4 & 28.7 & 22.8 & 52.7 & 40.8 \\
\hline $2.0-3.15$ & 26.7 & 12.5 & 27.4 & 28.7 & - & 23.5 & 36.7 & 26.9 \\
\hline $3.15-5.0$ & 24.3 & - & 20.2 & 20.0 & - & 19.8 & 26.9 & 22.4 \\
\hline
\end{tabular}

mineral soil. This effect was most evident for crystalline carbonates and slags. During a 9 years' soil incubation experiment with mineral and peat soils, Barkoff (1961) found that blast furnace slag had almost the same neutralising effect as finely ground limestone. The results of these experiments coincided very well with the Russian data (Avdonin 1976, Dovgopol 1980, Kulakova et al. 1988) and East German results (Ebert 1970).

\section{The Sauerbeck/Rietz and the modified Finnish pH Stat method}

Table 7 shows the test results for the silicate liming materials by fractions for the Sauerbeck/
Rietz and the Finnish pH Stat method. The Breivik calcite was included in this investigation with data from a previous investigation (Erstad et al. 1996). The lower values of the modified Finnish method occur because this method indicates the percentage of dissolved $\mathrm{Ca}$ in a material adjusted to be absolutely pure $\mathrm{CaCO}_{3}$ (adj. \% Ca), whereas the Sauerbeck/Rietz method measures the amount of dissolved $\mathrm{CaCO}_{3}$ equivalent as percentage of the total analysed $\mathrm{CaCO}_{3}$ in the sample. Thus the maximum value, by full reactivity, in a calcite would be 40.08 by the modified Finnish method, and 100 by the Sauerbeck/Rietz method. For both methods there were close correlations between the fineness of the materials and the reactivity, and the converter slags (K-Merox and BOF-Rauta) were 
Vol. 9 (2000): 333-348.

Table 5. Mean effect values (\%) and REGWQ tests for silicate liming materials, tested by fractions and measured relatively to Breivik calcite calcite $<0.063 \mathrm{~mm}, 24$ and 130 weeks after start of incubation in a natural Norwegian peat. The results of all the particle size fractions and the two reaction times were tested separately.

\begin{tabular}{|c|c|c|c|c|c|c|}
\hline REGWQ & Mean & & Liming material & & REGWQ & Mean \\
\hline Grouping & 24 weeks & Ranking 24 weeks & & Ranking 130 weeks & Grouping & 130 weeks \\
\hline
\end{tabular}

\begin{tabular}{rrl}
\hline & & \\
A & 140.0 & am-M-Merox \\
A & 116.3 & M-Merox \\
A B & 101.0 & BF-Rauta \\
A B & 100.0 & Breivik calcite \\
A B & 81.1 & BOF-Rauta \\
A B & 74.7 & Mg-BOF-Rauta \\
A B & 74.7 & K-Merox \\
B & 23.0 & Mn-Øye
\end{tabular}

$\begin{array}{rrl}\text { A } & 135.2 & \text { am-M-Merox } \\ \text { A } & 119.8 & \text { BF-Rauta } \\ \text { A } & 117.5 & \text { M-Merox } \\ \text { A } & 104.6 & \text { Breivik calcite } \\ \text { A } & 84.8 & \text { BOF-Rauta } \\ \text { A } & 76.9 & \text { K-Merox } \\ \text { A } & 75.8 & \text { Mg-BOF-Rauta } \\ \text { A } & 35.7 & \text { Mn-Øye }\end{array}$

Fraction $<0.063 \mathrm{~mm}$

$\begin{array}{llr}\text { BOF-Rauta } & \text { A } & 110.9 \\ \text { Mg-BOF-Rauta } & \text { A } & 100.8 \\ \text { K-Merox } & \text { A } & 100.3 \\ \text { Breivik calcite } & \text { A } & 100.0 \\ \text { am-M-Merox } & \text { A } & 98.5 \\ \text { BF-Rauta } & \text { A B } & 86.6 \\ \text { M-Merox } & \text { A B } & 81.0 \\ \text { Mn-Øye } & \text { B } & 50.4\end{array}$

Fraction 0.063-0.2 mm

$\begin{array}{llr}\text { K-Merox } & \text { A } & 113.3 \\ \text { Breivik calcite } & \text { A } & 110.7 \\ \text { BOF-Rauta } & \text { A } & 107.8 \\ \text { Mg-BOF-Rauta } & \text { A } & 106.5 \\ \text { am-M-Merox } & \text { A } & 103.2 \\ \text { BF-Rauta } & \text { A } & 100.6 \\ \text { M-Merox } & \text { A B } & 83.5 \\ \text { Mn-Øye } & \text { B } & 53.2\end{array}$

Fraction $0.6-0.8 \mathrm{~mm}$

$\begin{array}{lrl}\text { A } & 123.3 & \text { Breivik calcite } \\ \text { A B } & 88.1 & \text { am-M-Merox } \\ \text { A B } & 84.6 & \text { BF-Rauta } \\ \text { A B } & 80.6 & \text { M-Merox } \\ \text { A B } & 66.9 & \text { BOF-Rauta } \\ \text { A B } & 66.0 & \text { Mg-BOF-Rauta } \\ \text { A B } & 60.4 & \text { K-Merox } \\ \text { B } & 32.1 & \text { Mn-Øye }\end{array}$

$\begin{array}{lll}\text { A } & 85.5 & \text { Breivik calcite } \\ \text { A } & 68.7 & \text { am-M-Merox } \\ \text { A } & 59.3 & \text { Mg-BOF-Rauta } \\ \text { A } & 58.6 & \text { BF-Rauta } \\ \text { A } & 56.6 & \text { BOF-Rauta } \\ \text { A } & 56.3 & \text { M-Merox } \\ \text { A } & 51.8 & \text { K-Merox } \\ \text { A } & 27.6 & \text { Mn-Øye }\end{array}$

Fraction 1.0-1.4 mm

$\begin{array}{llr}\text { Breivik calcite } & \text { A } & 134.0 \\ \text { Mg-BOF-Rauta } & \text { A B } & 97.4 \\ \text { K-Merox } & \text { A B } & 97.2 \\ \text { BOF-Rauta } & \text { A B } & 96.5 \\ \text { BF-Rauta } & \text { A B } & 91.5 \\ \text { am-M-Merox } & \text { A B } & 88.9 \\ \text { M-Merox } & \text { A B } & 80.7 \\ \text { Mn-Øye } & \text { B } & 47.5\end{array}$

$\begin{array}{llr}\text { Breivik calcite } & \text { A } & 136.1 \\ \text { am-M-Merox } & \text { A B } & 106.5 \\ \text { Mg-BOF-Rauta } & \text { A B } & 93.3 \\ \text { K-Merox } & \text { A B } & 91.1 \\ \text { BOF-Rauta } & \text { A B } & 90.0 \\ \text { BF-Rauta } & \text { A B } & 89.5 \\ \text { M-Merox } & \text { A B } & 72.4 \\ \text { Mn-Øye } & \text { B } & 37.0\end{array}$

\begin{tabular}{lll} 
A & 41.2 & Breivik calcite \\
A & 29.2 & BOF-Rauta \\
A & 28.2 & M-Merox \\
A & 26.5 & BF-Rauta \\
A & 25.9 & K-Merox \\
A & 25.3 & Mn-Øye \\
A & 24.2 & Mg-BOF-Rauta \\
\hline
\end{tabular}

Fraction $2.0-3.15 \mathrm{~mm}$

\begin{tabular}{llr} 
Breivik calcite & A & 109.1 \\
K-Merox & A B & 84.2 \\
BF-Rauta & A B & 79.7 \\
Mg-BOF-Rauta & A B & 77.1 \\
BOF-Rauta & A B & 63.6 \\
M-Merox & A B & 61.6 \\
Mn-Øye & B & 34.3 \\
\hline
\end{tabular}


Erstad, K.-J. et al. Reactivity of silicate liming materials

Table 6. Reactivity in the course of 1 year and 5 years according to the Soil Incubation method for particle size groups $(\mathrm{mm})$ of the Breivik reference calcite and the silicate liming materials in a natural Norwegian peat. Average values for liming levels 1 and 2.

\begin{tabular}{|c|c|c|c|c|c|c|c|c|}
\hline \multirow{2}{*}{$\begin{array}{l}\text { Fraction } \\
\mathrm{mm}\end{array}$} & \multicolumn{8}{|c|}{ Liming material } \\
\hline & $\begin{array}{l}\text { Breivik } \\
\text { calcite }\end{array}$ & Mn-Øye & $\begin{array}{c}\text { M- } \\
\text { Merox }\end{array}$ & $\begin{array}{c}\text { K- } \\
\text { Merox }\end{array}$ & $\begin{array}{l}\text { am-M- } \\
\text { Merox }\end{array}$ & $\begin{array}{l}\text { BF- } \\
\text { Rauta }\end{array}$ & $\begin{array}{l}\text { BOF- } \\
\text { Rauta }\end{array}$ & $\begin{array}{c}\text { Mg-BOF- } \\
\text { Rauta }\end{array}$ \\
\hline & \multicolumn{8}{|c|}{ Reactivity in 1 year } \\
\hline$<0.063$ & 100.0 & 28.6 & 90.5 & 81.9 & 100.0 & 92.8 & 73.0 & 61.4 \\
\hline $0.063-0.2$ & 100.0 & 28.6 & 90.4 & 81.9 & 100.0 & 92.8 & 73.0 & 61.4 \\
\hline $0.2-0.4$ & 100.0 & 28.2 & 82.8 & 81.9 & 99.6 & 91.2 & 73.0 & 59.4 \\
\hline $0.4-0.6$ & 100.0 & 24.9 & 76.6 & 51.4 & 87.3 & 80.5 & 59.8 & 52.2 \\
\hline $0.6-0.8$ & 100.0 & 25.1 & 61.8 & 49.0 & 69.0 & 66.1 & 55.0 & 52.7 \\
\hline $0.8-1.0$ & 91.4 & 25.5 & 52.5 & 44.7 & 62.9 & 53.1 & 52.5 & 47.8 \\
\hline $1.0-1.4$ & 67.1 & 21.7 & 43.5 & 41.0 & 53.4 & 45.9 & 45.1 & 46.4 \\
\hline $1.4-1.6$ & 68.1 & 21.8 & 39.9 & 33.8 & 50.0 & 36.8 & 33.9 & 31.1 \\
\hline $1.6-2.0$ & 62.5 & 21.2 & 27.4 & 31.1 & - & 36.2 & 31.6 & 29.0 \\
\hline $2.0-3.15$ & 31.6 & 19.7 & 21.4 & 20.2 & - & 21.3 & 22.7 & 19.0 \\
\hline \multirow[t]{2}{*}{$3.15-5.0$} & 19.6 & - & 26.4 & 21.3 & - & 25.0 & 13.3 & 13.7 \\
\hline & \multicolumn{8}{|c|}{ Reactivity in 5 year } \\
\hline$<0.063$ & 100.0 & 46.2 & 90.5 & 83.6 & 100.0 & 92.8 & 83.4 & 76.1 \\
\hline $0.063-0.2$ & 100.0 & 46.2 & 90.5 & 83.6 & 100.0 & 92.8 & 83.4 & 76.1 \\
\hline $0.2-0.4$ & 100.0 & 46.2 & 90.5 & 83.6 & 100.0 & 92.8 & 83.4 & 73.7 \\
\hline $0.4-0.6$ & 100.0 & 37.7 & 90.5 & 71.1 & 100.0 & 80.5 & 79.7 & 69.8 \\
\hline $0.6-0.8$ & 100.0 & 34.2 & 90.5 & 69.7 & 100.0 & 70.1 & 68.9 & 69.7 \\
\hline $0.8-1.0$ & 100.0 & 34.2 & 57.0 & 65.1 & 100.0 & 70.1 & 71.1 & 65.7 \\
\hline $1.0-1.4$ & 100.0 & 26.5 & 52.3 & 65.5 & 100.0 & 65.0 & 64.4 & 67.0 \\
\hline $1.4-1.6$ & 100.0 & 31.7 & 48.5 & 68.7 & 100.0 & 59.5 & 50.4 & 52.9 \\
\hline $1.6-2.0$ & 92.3 & 24.9 & 53.8 & 66.6 & - & 58.5 & 52.8 & 56.4 \\
\hline $2.0-3.15$ & 78.1 & 24.8 & 44.6 & 60.6 & - & 57.5 & 45.7 & 55.5 \\
\hline $3.15-5.0$ & 48.9 & - & 44.0 & 46.8 & - & 42.4 & 45.3 & 45.6 \\
\hline
\end{tabular}

dissolved more effectively than the blast furnace slags.

It had previously been found (Erstad et al. 1996) that when testing carbonates with the Finnish method, the finest fraction $(<0.2 \mathrm{~mm})$ of $\mathrm{CaCO}_{3}$ normally achieved full dissolution (adj. $40.08 \% \mathrm{Ca}$ ), whereas the crystalline dolomites achieved approximately $40 \%$ dissolution (adj. $15 \% \mathrm{Ca})$. The same dolomite reactivity was found by Lindroos (1986), and he stated that $\mathrm{pH}$ 5 of this solution presents a very weak acid, and by decreasing $\mathrm{pH}$ to 4 and 3 the blast furnace slag increased most rapidly in solubility. The underestimation of the liming effect of dolomites and silicate liming materials by the Finnish meth- od should be taken into account when considering performance in soil. The Sauerbeck/Rietz method and in particular the Soil Incubation method reflects the dissolution in soil more accurately for these materials. Similarly, Crane (1930) showed that on the basis of $\mathrm{CaCO}_{3}$ equivalents, determined by titration with $\mathrm{HCl}$ (the official US AOAC method) using phenolphthalein as indicator, blast furnace slag and limestone, both finer than $0.15 \mathrm{~mm}$, had nearly the same effectiveness. This investigation confirms that there are only small differences in the ability to raise $\mathrm{pH}$ between carbonate and silicate liming materials of the same particle size when added to the soil. 
Vol. 9 (2000): 333-348.

Table 7. Reactivity by the Sauerbeck/Rietz and the modified Finnish pH Stat method for the Breivik reference calcite and the silicate liming materials.

\begin{tabular}{|c|c|c|c|c|c|c|c|c|}
\hline \multirow{2}{*}{$\begin{array}{l}\text { Fraction } \\
\mathrm{mm}\end{array}$} & \multicolumn{8}{|c|}{ Liming material } \\
\hline & $\begin{array}{l}\text { Breivik } \\
\text { calcite }\end{array}$ & Mn-Øye & $\begin{array}{c}\text { M- } \\
\text { Merox }\end{array}$ & $\begin{array}{c}\text { K- } \\
\text { Merox }\end{array}$ & $\begin{array}{l}\text { am-M- } \\
\text { Merox }\end{array}$ & $\begin{array}{c}\text { BF- } \\
\text { Rauta }\end{array}$ & $\begin{array}{l}\text { BOF- } \\
\text { Rauta }\end{array}$ & $\begin{array}{c}\text { Mg-BOF- } \\
\text { Rauta }\end{array}$ \\
\hline & \multicolumn{8}{|c|}{ The Sauerbeck/Rietz method ( $\%$ dissolved of total $\mathrm{CaCO}_{3}$ equivalents) } \\
\hline$<0.063$ & 100 & 7.47 & 39.25 & 66.74 & 96.60 & - & 82.99 & 76.01 \\
\hline $0.063-0.2$ & 99.2 & 3.78 & 22.45 & 44.61 & 47.24 & 53.64 & 61.77 & 44.68 \\
\hline $0.2-0.4$ & 76.4 & 2.67 & 15.52 & 18.33 & 18.67 & 26.38 & 37.34 & 25.92 \\
\hline $0.4-0.6$ & 53.7 & 1.04 & 11.26 & 15.24 & 13.57 & 16.39 & 31.27 & 18.17 \\
\hline $0.6-0.8$ & 45.8 & 0.49 & 9.50 & 10.10 & 9.65 & 13.84 & 18.29 & 11.72 \\
\hline $0.8-1.0$ & 33.6 & 0.60 & 7.53 & 8.43 & 7.93 & 10.88 & 14.61 & 8.49 \\
\hline $1.0-1.4$ & 26.7 & 0.36 & 6.05 & 7.01 & 6.62 & 7.76 & 8.95 & 7.15 \\
\hline $1.4-1.6$ & 18.7 & 0.36 & 5.95 & 5.62 & - & 5.95 & 7.85 & 6.26 \\
\hline $1.6-2.0$ & 16.9 & 0.20 & 5.50 & 5.22 & - & 4.89 & 5.01 & 4.61 \\
\hline $2.0-3.15$ & 12.6 & 0.13 & 4.26 & 3.60 & - & 4.55 & 4.24 & 3.76 \\
\hline $3.15-5.0$ & 8.7 & - & - & - & - & 4.41 & 3.55 & - \\
\hline
\end{tabular}

The modified Finnish pH Stat method (\% Ca dissolved of a pure $\mathrm{CaCO}_{3}$ material,

\begin{tabular}{ccccccccc} 
& \multicolumn{7}{c}{ corresponding to contain 40.08\% Ca equivalents) } \\
$<0.063$ & 39.88 & 4.16 & 14.65 & 24.82 & 21.01 & 19.03 & 32.36 & 27.44 \\
$0.063-0.2$ & 39.88 & 2.41 & 7.06 & 17.83 & 6.12 & 6.74 & 26.46 & 19.27 \\
$0.2-0.4$ & 29.62 & 1.29 & 3.30 & 10.30 & 1.79 & 2.50 & 19.89 & 11.40 \\
$0.4-0.6$ & 11.72 & 0.76 & 2.91 & 6.60 & 0.94 & 1.51 & 14.90 & 7.27 \\
$0.6-0.8$ & 6.18 & 0.62 & 2.39 & 5.16 & 0.84 & 1.29 & 11.98 & 5.38 \\
$0.8-1.0$ & 5.44 & 0.54 & 2.16 & 4.14 & 0.88 & 1.13 & 9.10 & 4.06 \\
$1.0-1.4$ & 3.77 & 0.38 & 1.85 & 3.49 & 0.75 & 0.89 & 8.00 & 3.85 \\
$1.4-1.6$ & 3.14 & 0.40 & 1.87 & 2.68 & - & 0.75 & 6.41 & 3.21 \\
$1.6-2.0$ & 1.99 & 0.28 & 1.80 & 2.44 & - & 0.58 & 5.02 & 2.66 \\
$2.0-3.15$ & 1.57 & 0.28 & 1.19 & 1.84 & - & 0.49 & 4.86 & 2.03 \\
$3.15-5.0$ & 0.73 & - & - & - & - & 0.38 & 2.21 & 1.44 \\
\hline
\end{tabular}

\section{Correlations between the three reactivity methods}

There appeared to be the same pattern of reactivity by materials and fractions between the Soil Incubation method in the silty loam, the Sauerbeck/Rietz and the modified Finnish pH Stat methods. The Sauerbeck/Rietz method, with some minor modifications, will be the forthcoming European standard for testing reactivity (prEN 13971. 2000). However, ENV will be widely used for comparison of liming materials under true agricultural conditions. The Finnish method is well accepted and widely used within its country of origin.
A general linear correlation equation for conversion of the results between the methods is given in the statistical part of materials and methods. The conversion factors and their standard deviations for all transformation of data between the methods were established by fraction (Table 8 ). The data of the Soil Incubation method are considered to be close to true values in agricultural soils, and it was very interesting to observe that the Finnish pH Stat method probably has an advantage compared with the Sauerbeck/Rietz method, because it allows a longer and less rough reaction and contact time between a less aggressive acid and the liming material. In spite of underestimation of some materials, it separates 
Erstad, K.-J. et al. Reactivity of silicate liming materials

Table 8. Conversion factors (convf.) and their standard deviations (SD, \%) by fraction for silicate liming materials, obtained by comparing the Soil Incubation, the Sauerbeck/Rietz and the modified Finnish pH Stat method. 7 liming materials tested.

\begin{tabular}{|c|c|c|c|c|c|c|c|c|c|c|c|c|}
\hline \multirow{3}{*}{$\begin{array}{l}\begin{array}{l}\text { Fraction } \\
\mathrm{mm}\end{array} \\
<0.063\end{array}$} & \multicolumn{12}{|c|}{ Data transformations between reactivity methods } \\
\hline & \multicolumn{2}{|c|}{$\begin{array}{c}\text { Sauerbeck } \rightarrow \\
\text { Inc. } 1 \text { year } \\
\text { convf. SD }(\%)\end{array}$} & \multicolumn{2}{|c|}{$\begin{array}{l}\text { Sauerbeck } \rightarrow \\
\text { Inc. } 5 \text { years } \\
\text { convf. SD }(\%)\end{array}$} & \multicolumn{2}{|c|}{$\begin{array}{l}\text { Finn. pHstat } \\
\rightarrow \text { Inc. } 1 \text { year } \\
\text { convf. SD }(\%)\end{array}$} & \multicolumn{2}{|c|}{$\begin{array}{c}\text { Finn. pHstat } \\
\rightarrow \text { Inc. } 5 \text { years } \\
\text { convf. SD }(\%)\end{array}$} & \multicolumn{2}{|c|}{$\begin{array}{l}\text { Finn. pHstat } \\
\rightarrow \text { Sauerbeck } \\
\text { convf. SD (\%) }\end{array}$} & \multicolumn{2}{|c|}{$\begin{array}{r}\text { Sauerbeck } \rightarrow \\
\text { Finn. pHstat } \\
\text { convf. SD }(\%\end{array}$} \\
\hline & 1.45 & 40.4 & 1.61 & 54.2 & 3.90 & 21.9 & 4.22 & 26.4 & 2.85 & 32.6 & 0.378 & 28.5 \\
\hline $0.063-0.2$ & 2.26 & 54.3 & 2.62 & 67.3 & 7.42 & 45.6 & 8.47 & 48.7 & 3.94 & 68.6 & 0.352 & 51.5 \\
\hline $0.2-0.4$ & 3.42 & 48.5 & 4.25 & 52.9 & 13.10 & 53.5 & 17.60 & 65.2 & 4.81 & 83. & 0.346 & 59.3 \\
\hline $0.4-0.6$ & 4.53 & 83.2 & 6.74 & 109 & 15.52 & 50.3 & 24.14 & 70.1 & 5.35 & 96.2 & 0.351 & 65.9 \\
\hline $0.6-0.8$ & 6.31 & 116 & 11.43 & 147 & 14.67 & 43.2 & 25.88 & 62.0 & 4.66 & 96. & 0.474 & 85.9 \\
\hline $0.8-1.0$ & 6.00 & 96.5 & 10.55 & 117 & 15.04 & 40.9 & 26.21 & 52.3 & 4.14 & 87. & 0.427 & 66.8 \\
\hline $1.0-1.4$ & 6.66 & 119 & 12.21 & 130 & 14.09 & 51.5 & 25.85 & 57.9 & 3.82 & 90.6 & 0.502 & 72.5 \\
\hline $1.4-1.6$ & 7.07 & 106 & 13.86 & 124 & 12.53 & 44.5 & 23.41 & 56 & 2.89 & 90.5 & 0.558 & 63.1 \\
\hline $1.6-2.0$ & 9.93 & 130 & 18.10 & 146 & 13.69 & 52.1 & 24.81 & 67.3 & 2.85 & 101 & 0.648 & 72.4 \\
\hline $2.0-3.15$ & 10.57 & 151 & 21.92 & 166 & 12.86 & 57.0 & 25.33 & 67.1 & 2.99 & 108 & 0.788 & 95.3 \\
\hline $3.15-5.0$ & 2.79 & 19.7 & 6.03 & 36.2 & 13.58 & 92.7 & 26.71 & 83.5 & 6.64 & 107 & 0.354 & 107 \\
\hline
\end{tabular}

the fractions very clearly, making the tests sensitive. This is shown as smaller SD values when data are transformed from the modified Finnish method to the Soil Incubation method.

The SD values of the conversion factors appeared partly to be quite large, and revealed different behaviour of the reactivity methods. The magnitude of the uncertainty and the variations for a liming material is discussed in Erstad et al. (1996). It was found that they would be lower than indicated in Table 8 by each fraction, because these deviations went in arbitrary directions, and as vectors counteracted each other.

\section{Conclusions}

This investigation made a ranking of seven Northern European silicate liming materials possible, internally and compared them with a reference calcitic liming material. Correlations between data from three important reactivity meth- ods were established by conversion factors and with data of statistical reliability for these silicate liming materials. It was shown that converter slags with their high proportion of free oxides are superior in raising the $\mathrm{pH}$ in slightly acid mineral soils, whilst blast furnace slags are equally as effective in acid peaty soils. In the fine particle range, amorphous blast furnace slag normally has a higher reactivity than its nonamorphous variant. In the short-term converter slags were as efficient as calcite, and in the longterm blast furnace slags also showed the same efficiency.

Acknowledgements. This work has been funded by companies of the Northern European steel industry: Øye Smelteverk (Tinfos Jernverk AS), SSAB Merox AB and in particular SKJ Companies Ltd. (Rautaruukki Group), which additionally financed this final publication and participated in the production of this paper. Dr. Anne Erstad-van der Vlugt, Consultative Agronomists, and Mr. Brian Annis, Needham Chalks Ltd., UK, have kindly revised the manuscript. The investigations were initiated within the CEN framework, and the need for new knowledge to further the work of the standardisation of European liming materials (CEN/TC260/WG3). 


\section{References}

Avdonin, N.S. (ed.). 1976. Liming of acid soils. "Kolos", Moscow. 304 p. (in Russian).

Barkoff, E. 1961. Masuunikuonan ja hienofosfaatin maata kalkitseva vaikutus pitkäaikaisen laboratoriokokeen perusteella. Journal of the Scientific Agricultural Society of Finland 33: 194-202. (in Finnish).

Bondorff, K.A. 1950. Om bestemmelse av jordens rumvægt. Tidsskrift for Planteavl 53: 450-560. (in Danish).

Carter, O.R., Collier, B.L. \& Davis, F.L. 1951. Blast furnace slags as agricultural liming materials. Journal of the American Society of Agronomy 43: 430-433.

Chichilo, P.P., Armiger, W.H., Specht, A.W. \& Whittaker, C.W. 1954. Plant nutrients from slag - Furnace slag as a source of plant nutrients and its liming effectiveness relative to limestone. Journal of Agricultural and Food Chemistry 2: 458-462.

Crane, F.H. 1930. A comparison of some effects of blast furnace slag and of limestone on an acid soil. Journal of the American Society of Agronomy 22: 968973.

Deryugin, I.P. \& Kultyshev, V.P. 1973. On the use of metallurgical slags as lime fertilizers. In: Avdonin, N.S. (ed.). Problems of Liming of Acid Soils. "All-Union Institute for Fertilizers and Agricultural Soil Science", Gorki. p. 139-141. (in Russian).

Dovgopol, V.I. 1980. Metallurgical slags in agriculture. "Metallurgia", Moscow. 40 p. (in Russian).

Ebert, K. 1970. Die Wirkung von Kalken und kalkhaltigen Schlacken in Abhängigkeit von der Korngröße auf saurem, magnesiumarmem Sandboden. Zeszyty Problemowe Postepów Nauk Rolniczych 105: $181-187$.

EN 12947. 2000. Liming materials - Determination of magnesium content - Atomic absorption spectrometry. European Committee for Standardization. Brussel. 9 p.

Erstad, K.-J. 1992. A laboratory soil incubation method to assess reactivity of liming materials for agriculture. Norwegian Journal of Agricultural Sciences 6: 309-321.

- , Erstad, A., Rex, M. \& Luukkonen, E. 1994. Quality of silicate liming materials from Northern Europe assessed by three methods of testing reactivity. Fureneset Forskingsstasjon Rapport 1/1993. 120 p.

- , Rex, M., Putro, J., Linke, J. \& Runge, P. 1996. Correlations between current methods for determining reactivity of chalks and soft limestones, crystalline limestones, crystalline magnesian limestones, and crystalline dolomites for agricultural purposes. Norwegian Journal of Agricultural Sciences 10: 385-396.

Hodgson, J.M. 1974. Soil survey of England and Wales. Technical monograph No. 5. Soil Survey Field Handbook. Harpenden. 99 p.

Jaakkola, A. 1988. Slagg som kalkningsmedel. NJF-seminar nr. 123. NJF-Utredning/Rapport nr. 46. p. 6165. (in Swedish).

Kulakova, V.P., Velichko, V.A., Kuzmich, M.A. \& Liventsev, Yu.V. 1988. Liming of acid soils by converter slags. Chemicalization of Agriculture 4: 62-64. (in Russian).

Lindroos, K.-H. 1986. Kalkitus- ja maanparannusaineiden liukoisuudesta. Valtion maatalouskemian laitos 1985. Vantaa. p. 40. (in Finnish).

Maclntire, W.H., Winterberg, S.H. \& Clements, L.B. 1946. Certain "glassy" and crystalline calcium silicate materials: Their distinctive behavior and liming effectiveness as registered by plant response and soil pH. Soil Science Society of America Proceedings 10: 71-80.

Myhr, K. 1987. Stålverksslag som kalkingsmiddel. Norsk Landbruksforskning 1: 141-146. (in Norwegian).

- 1988. Forsøk med stålverksslagg NFJ-seminar nr. 123. NJF-Utredning/Rapport nr. 46. p. 66-70. (in Norwegian).

- \& Erstad, K.-J. 1996. Converter slag as a liming material on organic soils. Norwegian Journal of Agricultural Sciences 10: 83-94.

Norges Standardiseringsforbund 1987. Kalkingsmidler for landbruket. Norsk Standard NS 2885. Versjon 2. Norges Standardiseringsforbund, Oslo. 7 p. (in Norwegian).

Ogorodnikov, L.P. \& Novikov, A.E. 1986. Industrial limecontaining products for the liming of soils. Chemistry in Agriculture 24 (N12): 13-15. (in Russian).

Penninck, R., Verdonck, O. \& de Boodt, M. 1986. Het gebruik van gemalen L.D.-slakken als Kalk. Mededeling van de Faculteit der Landbouwwetenschap, Rijksuniversiteit Gent 51/1. p. 23-29. (in Dutch).

prEN 12944-3. 2000. Fertilizers and liming materials Vocabulary - Part 3: Terms related to liming materials. European Committee for Standardization. Brussel. 16 p.

prEN 12945. 2000. Liming materials - Determination of neutralizing value - Titrimetric method. European Committee for Standardization. Brussel. $10 \mathrm{p}$.

prEN 13475. 2000. Liming materials - Determination of calcium content - Oxalate method. European Committee for Standardization. Brussel. $8 \mathrm{p}$.

prEN 13971. 2000. Liming materials - Determination of reactivity - Potentiometric titration with hydrochloric acid. European Committee for Standardization. Brussel. $10 \mathrm{p}$.

Rex, M. \& Munk, H. 1989. Düngung mit silikatischen Kalken und Einfluß auf Ertrag sowie $\mathrm{SiO}_{2}$-Gehalte in Boden und Pflanze. VDLUFA-Schriftenreihe 28/ 1989. Kongressband 1988, Bonn, Teil II. p. 389-402.

SAS Institute Inc. 1985. SAS Language Guide for personal computers. Version 6 edition. Cary, North Carolina. $429 \mathrm{p}$.

- 1987. SAS/STAT Guide for personal computers. Version 6 edition. Cary, North Carolina. 1028 p.

- 1988. SAS Procedures Guide. Release 6.03 edition. Cary, North Carolina. 441 p.

Sauerbeck, D. \& E. Rietz 1985. Ein Verfahren zur Bestimmung der Reaktionsfähigkeit kohlensaurer Düngekalke. Landwirtschaftliche Forschung Sonderheft 41: 682-690. 
Erstad, K.-J. et al. Reactivity of silicate liming materials

Scheffer, F. \& Schachtschabel, P. 1979. Lehrbuch der Bodenkunde 10. Auflage. Ferdinand Enke Verlag, Stuttgart. $394 \mathrm{p}$.

Simán, G. 1984. Undersökning av Si-Mn-slagg från Øye Smelteverk A/S, Norge, särskilt med hänsyn till desse skördehöjande verkan och kemiska markeffekter. Swedish University of Agricultural Sciences, Department of Soil Sciences, Division of Soil Fertility Report 160. 30 p. (in Swedish).

Sonina, K.I. \& Melnikova, M.N. 1971. Effect of lime-containing industrial products on the growth and development of some agricultural plants and the quality of yield. Chemistry in Agriculture 9 (N7): 9-14. (in Russian).

Statue Book of Finland. 1994. Maa- ja Metsätalousministeriön päätös eräistä lannoitevalmisteista. Suomen Säädöskokoelma Nr 46/1994. (in Finnish).
Thomas, G.W. 1982. Exchangeable cations. In: Page, A.L. et al. (eds.). Methods of Soil Analysis. Part 2. Chemical and Microbiological Properties. 2nd edition. Madison, WI: American Society of Agronomy. p. $159-164$.

Vetter, H. 1974. Feldversuchsergebnisse über die Düngerwirkung von Konverterkalk. Die Phosphorsäure 30, 2: 265-271.

Volk, G.W., Harding, R.B. \& Evans, C.E. 1952. A comparison of blast furnace slag and limestone as a soil amendment. Ohio Agricultural Experiment Station Research Bulletin 708. Wooster, Ohio. 19 p.

Yagodin, B.A., Reshetnikova, N.V. \& Mokhamed Al-Mosava, A. 1994. The effect of metallurgical slags on seed germination and the content of heavy metals in the soil and the plants under their long-term interaction with soil. Agrochemistry 9: 84-94. (in Russian).

\title{
SELOSTUS
}

\section{Pohjois-Euroopan silikaattisten kalkitusaineiden reaktiivisuus astiakoemenetelmällä ja kahdella pH-staattisella menetelmällä arvioituna}

\author{
Karl-Jan Erstad, Nikolai Y. Konovalov, Jukka Putro, Martin Rex ja Elsa Luukkonen \\ Consultative Agronomists, Norja, Regional Research Computer Centre, Venäjä, Rautaruukki, Suomi, \\ Versuchsanstalt Kamperhof, Saksa ja Kasvintuotannon tarkastuskeskus, Suomi
}

Silikaattisten kalkitusaineiden reaktiivisuutta tutkittiin norjalaisella ferromangaanikuonalla, kolmella ruotsalaisella ja kolmella suomalaisella masuuni- ja konvertterikuonalla. Vertailumateriaalina kokeissa oli kiteinen kalsiitti. Kolmea reaktiivisuuden määritysmenetelmää käytettiin kuonien luontaisen kalkitusvaikutuksen selvittämiseksi ja standardisoinnissa tarvittavien matemaattisten riippuvuuksien laskemiseksi.
Astiakokeiden perusteella konvertterikuonat ja amorfiset masuunikuonat olivat kalsiittia tehokkaampia hietamaassa, kun taas happamassa turvemaassa kuonien ero kalsiittiin oli pienempi. Pitemmillä testausajoilla kuonat olivat fraktioittain tarkasteltuna lähes yhtä tehokkaita kuin kalsiitti. Joskus kalsiitti oli hieman tehokkaampi hienoissa raeluokissa, kun taas kuonat olivat ylivoimaisia karkeammissa raeluokissa. 